International Journal of Social Sciences and Humanities
Available online at http://sciencescholar.us/journal/index.php/ijssh
Vol. 3 No. 1, April 2019, pages: $160 \sim 170$
e-ISSN: 2550-7001, p-ISSN: $2550-701 \mathrm{X}$
https://doi.org/10.29332/ijssh.v3n1.277

\title{
Religious Moderation Discourse in Plurality of Social Harmony in Indonesia
}

\begin{abstract}
CrossMark
Yudhi Kawangung a

Article history: Received 27 August 2018, Accepted: 31 December 2018, Published: 25 April 2019



Keywords

Abstract

The study of religious tolerance this century has been entering the culmination point of saturation, in which it is no longer viewed relevantly with technology 4.0 or it is generally called millennium generation. Technology development is directly proportional to social life because humans enter the digital era in which the actualization and self-existence are prioritized. Therefore, in social interaction, it often makes friction and horizontal conflict and even social media felt more concerned about. Tolerance is gradually degraded in its implementation because it is assumed that tolerance givers have a higher level (majority) than the recipient of tolerance (minority). In this case, the tolerance model needs contextual modification, namely religious moderation as a fundamental of more acceptable social interaction among citizens and netizens.
\end{abstract}

e-ISSN: 2550-7001, p-ISSN: 2550-701X ๑ Copyright 2019. The Author. SS Journals Published by Universidad Técnica de Manabí. This is an open-access article under the CC BY-SA 4.0 license (https://creativecommons.org/licenses/by-sa/4.0/) All rights reserved.

\section{Contents}

Abstract. 160

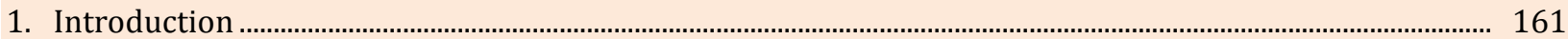

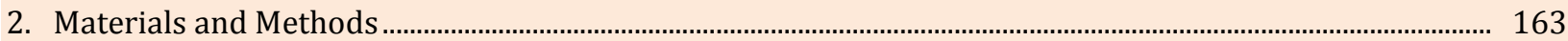

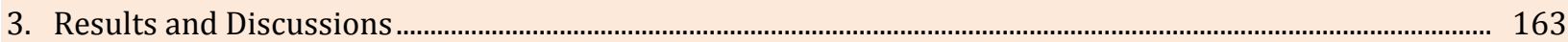

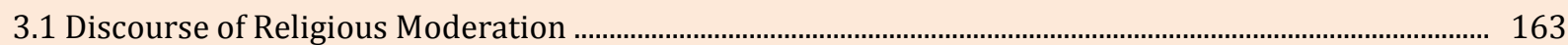

3.2 Discourse of Indonesian Plurality ................................................................................................................... 164

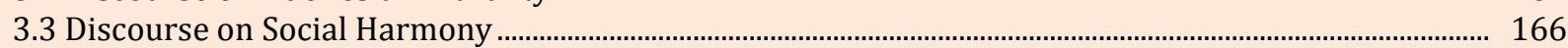

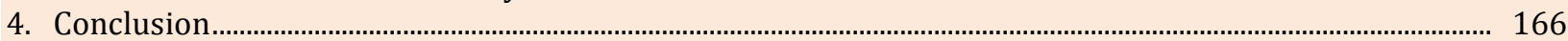

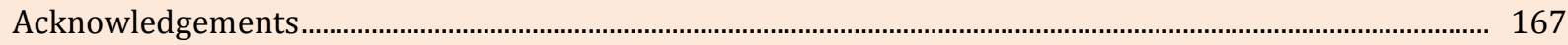

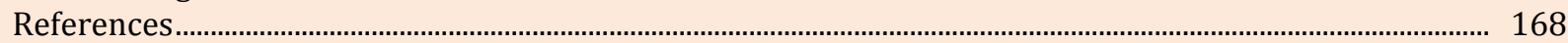

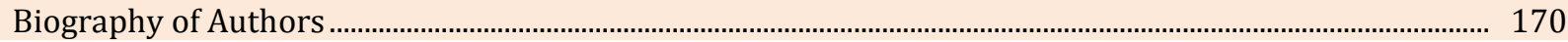

a Sekolah Tinggi Agama Kristen Teruna Bakti Yogyakarta, Indonesia 


\section{Introduction}

Indonesia is a country consisting of various tribes, races, customs and religions whose social communities live in thousands of islands. The spread of population on the islands is uneven. Most densely populated including Java island inhabited by 58\%, Sumatra island 21\%, Sulawesi island 7\%, Kalimantan island 6\%, Bali and Nusa Tenggara $6 \%$ while on the islands of Papua and Maluku are inhabited by 3\% of Indonesia's population. This shows that the number of people living on an island is different from others in Indonesia.

Based on the data and information above, it cannot be denied that plurality in society is a reality within the Republic of Indonesia. The term "plural" derives from Latin "plus" to "pluralist" which means "more" or more than one; (Kamus Besar Bahasa Indonesia Online Dictionary). In Indonesian, there are similarities of various elements. This situation in Indonesia is expressed with the term "compound" which derives from Arabic. In this writing, its emphasis on the notion of the plural "more than one" referring to ethnicity, culture, religion, language, and custom. Plurality in Indonesia is very complex. In the context of plurality, the Indonesian nation is able to establish itself as a nation that has national values. The reality of plurality is not highlighted as a distinguishing factor but it is considered as a gift in fostering the spirit and unity.

Diversity or more often called pluralism is the reality of Indonesian people. A sense of togetherness over differences in ethnicities, languages, and religions, the Indonesian nation was successfully realized by a sense of being in the same boat because they were colonized by the Dutch. On the other hand, the religious sentiment was very sensitive matter (Robiyanto et al., 2012).

The founders of the Indonesian country were very wise and had a long view, so they can formulate a national country. This is explained in the Opening of the 1945 Constitution:

That freedom is the rights of whole nations of the world and therefore, kinds of colonials should be ceased because of inhumanity and justice. And Indonesian independence movement struggles have been in the right time and happiness to bring Indonesian people into the gate of Indonesian freedom; independently, unity, Sovereignty, and just and prosperous. In the name of God and glorious encouraged desire to have free national life, hereby Indonesian declared their independence. Afterwards, to form the Indonesian government that protects the whole people and heroic blood struggle and developing general prosperity, education of Indonesian and taking part in International affairs based on independent purposes, peacefulness and social justice, thus Indonesian National Independence formulated in the Republic of Indonesian constitution to state the Sovereign Republic of Indonesian Government structures based on Believe in One Supreme God, Just and Civilized Humanity, The Unity of Indonesia, Democracy wisely led by the wisdom of deliberations among Representatives, Social Justice for the whole Indonesia. (Indonesian State Secretariat, 1983).

The quote above states that all activities within the country are regulated by the Law. A Yewangoe said:

The preamble of the 1945 Constitution requires unity which encompasses the entire Indonesian nation in the normal sense of the country, the administration of the state, and every citizen must prioritize the interests of the state before the interests of groups or individuals (Yewangoe, 2002).

Based on Preamble of the 1945 Constitution (UUD 1945), Pancasila is said to be the state foundation or ideology or a philosophy or point of view of national life, while the 1945 Constitution is a constitutional principle for "basic rules." Therefore, The Republic of Indonesia is in according to Pancasila and the 1945 Constitution. It was later confirmed by President Joko Widodo, that "Actually it was finished. The problem of diversity has been resolved because it has become the agreement of the founders of this nation" (Directorate General of Christian Community Protection, 2018).

The implementation of National Development cannot be separated from the role of all Indonesian people and recognized religions and it is expected to provide a moral foundation for national development. Humans are basically social beings and also political. Social characteristic refers to life together with others, communicating (Manalu et al., 2007) and exchanging experiences, ideas and sharing emotions and so on.

Kawangung, Y. (2019). Religious moderation discourse in plurality of social harmony in Indonesia. International Journal of Social Sciences and Humanities, 3(1), 160-170. https://doi.org/10.29332/ijssh.v3n1.277 
Political characteristic refers to the relationships held by individuals with others as long as humans take part in social groups (Nugroho, 2003; Bouman in Rusmala, 2004).

In essence, regulations such as Joint Regulation of the Minister of Religion and Minister of Home Affairs No. 9, 2006 and No. 8, 2006 concerning Guidelines for the Implementation of Tasks of Regional Heads/Deputy of Regional Heads in the Maintenance of Religious Harmony, Empowering Religious Community Forums and Establishing Houses of Worship. Previously there was a Joint Decree of the Minister of Home Affairs and Minister of Religion No. 01/BER.MDN-MAG/1969 dated on September 13, 1969, concerning the establishment of places of worship and religious activities, followed by:

1) Minister of Religion Decree No. 70, 1978 concerning religious broadcasting guidelines.

2) Minister of Religion Decree No. 77, 1978 concerning foreign assistance.

3) SKB of the Minister of Religion and Minister of Home Affairs No. 1, 1979 concerning the procedures for implementing religious broadcasting and foreign assistance to religions in Indonesia.

4) Minister of Religion Instruction No. 5, 1981 concerning guiding the implementation of $d a^{\prime} w a h /$ sermons/religious lectures (Sudomo, 2002).

It seems to limit creativity in the applicative space of religion by various religious followers in Indonesia. The 1945 Act that guarantees religious freedom for the people of Indonesia, as written in CHAPTER XI article 29 paragraph 2. Sindo Newspaper wrote: "Speech of the President of the Republic of Indonesia when being awarded The World Statesman by The Appeal of Conscience Foundation in New York (30/5) and it seems to be impressively "We will protect minority groups and ensure that no one is treated discriminatorily". However, at the level of mobilization and execution, it is still quite weak because there are no steps or efforts to realize what is conveyed in the content of the speech. Further, the statement of Kontras Executive Coordinator, Haris Azhar acknowledged that intolerance groups actually happened in the era of SBY's administration. He said that since the last four months there had been around 60 cases of intolerance. This number was considered to have significantly increased compared to the previous year "(Koran Sindo, Wednesday, June 5, 2013). In addition to concerning with Joint Regulation of the Minister of Religion and Minister of Home Affairs Number 9, 2006 CHAPTER IV concerning the Establishment of Houses of Worship (Dirjen Bimas Kristen, 2011), especially in several points, they seem that there is discrimination/inhibition on the community of faith with a smaller number of followers in carrying out their worship. To accommodate the various existing beliefs, the government in the past had politely arranged them as follows:

The Presidential Decree (Penpres) No. 1/PNPS/1965 junto Law No.5/1969 concerning the Prevention of Abuse and Blasphemy of religion in its explanation, each article explains that Religions followed by the majority of Indonesian population are Islam, Christianity, Catholic, Hindu, Budha, and Confucian. Even so, it does not mean that other religions and beliefs may not develop in Indonesia and even the government is obliged to encourage and foster the development of the religions. In addition, during the New Order government, there has been a belief in God Almighty, aimed at some people who believed in the existence of God, but they are not adherents of one of the majority religions (http://id.wikipedia.org/wiki/Agamaagama_di_Indonesia).

In this case, how is the attitude of religious people in carrying out their faith mission in the context of a plurality of Indonesia? How is their faith mission in relevant words and actions in the context of plural societies in Indonesia, not to make other problems in social reality in Indonesia? The problems encourage the writer to think and study the concept of Religious Moderation in Social Harmony which is relevant in the context of plural societies in order to obtain balanced and inclusive harmony in practical domains on pluralistic Indonesian society. "The way of solving the problems is to bring them by prayer and active participation in various government policies and programs. Leaders of religious communities need to build social harmony and national unity" (Pelita Kristen Magazine, 2018). Then as it was reported by Masduki, a Lecturer at UIN Suska Riau, mediated that:

Social interaction in principle is the best way to unite social integration. This integration effort does not aim at making human as a community, but to establish social relationships to live in mutual respect for differences among communities and other differences existing within the communities. The difference is actually a natural thing to happen but not a dispute yet in the acknowledgment of diversity or plurality (Masduki, 2014). 
The idea is carried out in order that the religious mission can be better understood by all Indonesian citizens in the context of a pluralistic society so that the effort of relevant religious life is found in polite social harmony in the context of Indonesian plurality.

Referring to the problem above, the purpose of this paper will be oriented on attitudes concerning religious moderation that have a positive impact on social harmony, because of the concept of religious moderation, social harmony in Indonesia will be a description to provide understanding leading to religious responsibility and harmony in social relations.

This research emphasizes on a literature review to find the answers of Religious Moderation in the Plurality of Social Harmony in Indonesia. This research describes the substation of the contents of each section with the formulation of the question: how is the logical construction of religious moderation in the context of Indonesian plurality in social harmony?

Referring to the formulation of the problem above, the purpose of this study is oriented to the logical construction of religious moderation which has a positive impact on social harmony. Description of the study is also to provide perspectives leading to religious responsibility and harmony in social relations.

\section{Materials and Methods}

In this literature review, it is carried out by understanding the description of each part in the objective, by describing Descriptive Analysis that means descriptive, referring to the effort in finding data through library resources related to the subject matter. Based on the data, the analysis and interpretation focus on the problem is related to religious moderation in a plurality of social harmony in Indonesia, to determine and find the answers as well as the inclusive implementation of national and state life.

Another method used by the author in this section is a descriptive method. According to the Indonesian dictionary, the descriptive term means "clearly and detail explanation or illustration by words" (Tim Penyususn Pusat Pembinaan dan Pengembangan Bahasa, 1997). Descriptive method is a type of research or study method by describing, illustration or explanation by words. Some procedures adopted by this descriptive method are; searching for data in the bible, journals, e-book software, other correlated literature.

This research requires data which is very closely related to the construction of religious moderation logic of social harmony in Indonesia, therefore the theoretical framework of data through literature studies focuses on data needs and analysis. Data collection and analysis (data analysis process, including effective data collecting technique) is applied for research objectives. The research analysis was carried out together with data collection namely "the process of analyzing qualitative data as transforming data covering three processes, namely: description, analysis, and interpretation" (Subagyo, 2004). Based on this information, the analysis includes Reading, Learning and Searching Data; Data Reduction; and Data Presentation.

\section{Results and Discussions}

\subsection{Discourse of Religious Moderation}

Religions contact in Indonesian plurality implies two sides, namely positive side as unifying wealth while negative side makes fanaticism in exclusive and primordial radicalism that finally it makes social conflict among religious communities in harmony of the plurality of the nation. According to Muhammad Sharif, each conflict is triggered by social, political and economic interests (Sharif, 2004). The solution to the conflict based on the principle of spiritual humanization can make more constructive interaction because it emphasizes on harmonization, stabilization, and so on. Spiritual humanization recognizes the physical role, logical reason and spirit, and regards human life as unity and harmony. The principle of united and harmonious life becomes the ideology existed in spiritual humanization (Masduki, 2014).

As it has been already explained before that religion is an inseparable part of national life, state, and Indonesian society. Therefore, religious responsibility does not ignore individual responsibility as Indonesian citizens, religion must be consistent to carry out religious practices in accordance with their belief. On the

Kawangung, Y. (2019). Religious moderation discourse in plurality of social harmony in Indonesia. International Journal of Social Sciences and Humanities, 3(1), 160-170. https://doi.org/10.29332/ijssh.v3n1.277 
other hand, religion for Indonesian citizens must comply with government regulations and participate in all aspects of National Development as the implementation of Pancasila. For this reason, religious communities in Indonesia must be able to cooperate with the government and also followers of other religions to create a just and prosperous Indonesian state. Therefore, this paper is limited in the context of the meaning of religious ways to make social harmony in Indonesia (Sairin et al., 2001).

Religious moderation is creative effort to develop an attitude of the diversity of various tensions (constrains), such as between claims of absolute truth and subjectivity, between literal interpretations and arrogant rejection of religious precept, also between radicalism and secularism (Ditjen Bimas Kristen, 2019). Furthermore, religious moderation is understood to bring about moderate and tolerant types of religion. Furthermore, Aholiab Watloly emphasized that religious moderation is a supreme reflection of the inner vision of Pancasila unearthed from the national spiritual universe, continues to make the gentle religious heart and wise religious mind in the Indonesian nation.

In line with various religions, the immanent subject is a part of it; hence, it is important to be investigated because with the understanding of religious identity correctly, both by its followers and other believers in the context of Indonesian plurality, it is more likely that the ideals of the nation will be more apparent in the reality of inclusive social harmony in religious encounters in Indonesia, which is based on Pancasila and the Constitution 1945. This is carried out in the spirit of "unity in diversity" which implies work together in harmonious tolerance, so it is impossible "no" to reach a just and prosperous Indonesian society in accordance with the spirit of the United Republic of Indonesia (NKRI).

\subsection{Discourse of Indonesian Plurality}

A plurality (Clendenin, 1995b and; Carson, 1996). Indonesia is an unavoidable reality; this reality includes tribes, religions, races, groups and geographical location influencing systems of civilization that vary in adding real complexity. This plural context is inevitable from the encounter among beliefs that have been classified into five major religions; Hindu. Buddha, Islam, Protestant Christianity, and Catholic Christianity as well as native religion and the growing religious beliefs (Simatupang, 1997).

In plural reality in Indonesia, religion is an important part of the Indonesian nation that carries out the task of its faith in accordance with its holy book to determine national harmony as the embodiment of religious reflection in practical level; In other words, religious people have a responsibility to bring harmony in the reality of pluralistic Indonesian society. Therefore, religion is confronted with the challenges of carrying out the duties of faith in words and actions. "Even though diversity is actually born because of our limitations, we must complement each other in synergy, understand each other, and respect each other" (Pelita Kristen Magazine, 2018).

T.B. Simatupang asserted that Indonesia was founded on the basis of Pancasila as an important element to maintain and strengthen the national unity and unitary state. Pancasila was born as a historical challenge, which may be a little different, all principles can be accepted and supported by all levels of Indonesian society. Pancasila has a very strong emotional dimension so that it is one of the sources to struggle for justice and equality for all citizens as well as the most complete basis national role of the ideology (Simatupang, 1997). Pancasila accommodates all religious spiritual values of harmonious social relation in Indonesia. The same opinion was stated by P.D. Latuihamallo (1999):

Indonesian society is heterogeneous. As the results of perceptions about which one is good or not, and which one is evil, everyone who stays in a house is protected, defended and allowed to manage themselves, develop intelligence, service life together as a big family. A heterogeneous society based on Pancasila must be able to create awareness of unity, brotherhood, and solidarity" (1999:23).

Whereas institutionally, the basic rules of the State have been wisely elaborated by the founding fathers to become a formal implementation guideline in all constitutional components in the unitary State of the Republic of Indonesia which also includes guarantees for religious polite ways in Indonesia. According to Sutarno (2004):

With the existence of Pancasila and the Constitution. 1945 Article 29, it becomes clear that the nation and the Indonesia government recognize, respect and guarantee the existence of plurality (diversity) of 
religions and beliefs in the lives of Indonesian people. Based on the Constitution. 1945, different religions and beliefs have the same rights and obligations in and for the life of the nation and state. In this case, it means that the government should be fair to the existed religions and beliefs in order to fulfill the rights and obligations of each as well as possible. On the other hand, in realizing the freedom of rights and obligations of each religion and belief, they must always remember the purpose and idea of unity which underlies the inclusion of the question of the One and Only God in Pancasila and the Constitution 1945. In other words, all religions and beliefs in life and their activities must take responsibility in maintaining the unity and unitary of the whole nation "(2004: 226).

In line with the opinions above, the leaders of interreligious F.L. Cooley (1997), wrote:

The efforts of Christians as "ambassadors of Christ" carry out "the ministry of peace" insisting their serious attention to historical, theological dimensions and practical and religious pluralism and inter-religious community relations "(1997:170).

Diputhera (1996), revealed his anxiety of freedom of thought.

In the effort of establishing the nation and Indonesian government based on Pancasila, it needs awareness of the nation, state, and religions because only with the presence of national, state and religious awareness, we will be able to survive and sustain the life of our nation and state and religions (1996:70).

Furthermore, he asserted,

Since the Buddha's time, tolerance among religious people has become a problem, because it becomes the basis for the realization of the harmony of the life of religious people. The Buddha tried to maintain tolerance among religious people at that time so that the harmony of the life of religious people can still be well implemented (Ibid:71).

A Hindu religious leader said,

We are grateful that as a nation with the philosophy of Pancasila, Indonesia has a way of life and the development of entirely Indonesian people. It means that Pancasila is trying to realize prosperous Indonesian society, advanced and modern nation, having a high level of life, and not neglecting faith and charity, psychological efforts and religious practices, increasing the higher value of human life than just emphasizing worldly life or mere materialism (Atmaja, 1996).

Permadi (1996), a follower of Belief in God Almighty also said emphatically.

Moral can be a foundation and guideline for humans to consider the feelings and interests of others. And it can also be controlled by humans to regulate their lives more than majoring "ego" impulses. The moral bond will be strong if it is sourced and harmonizes with religious values. This means that religion does not only mean individual but also has social meaning for the life of the nation and state "(1996:94).

In the World Islamic Mass Media Conference in Jakarta, Djohan Efendi (1996), stated:

The Republic of Indonesia is not a religious country and not a secular state, it is an expression: we do not assimilate Pancasila. This expression is also negation or disclaimer (1996:150).

Then he continued,

Presumably, it is time to speak more clearly how the relationship between religion, ideology, and politics in the life of our nation is. President Suharto repeatedly asserted that Pancasila Society aspired by the Indonesian people is the only socio-religious society, namely, society is kinship and respected by divine values or religious values (Ibid:151).

Theoretically, the quotations above have been relevant and related conceptually that can be used as a theoretical reference because the studies are the same referring to the presence of religions in a plurality of Indonesia. Discourse is simple and practical one in relevant context in Indonesia that implies the meaning of

Kawangung, Y. (2019). Religious moderation discourse in plurality of social harmony in Indonesia. International Journal of Social Sciences and Humanities, 3(1), 160-170. https://doi.org/10.29332/ijssh.v3n1.277 
religious moderation to make social harmony, which in turn all citizens of other faiths can achieve just ideals and prosperous nation today.

\subsection{Discourse on Social Harmony}

Harmony is not the last value, but it is only a means that must exist as a condition sinequanon to achieve further objectives, namely safe and peaceful situation. This situation is appropriate for all parties in the community in order to increase the spiritual and material values needed to achieve a higher level of life. Robert M. Wallace states that the relations among individuals and societies become a fundamental issue in social thought (1996:468). Religious tolerance does not happen on its own for political and factor reasons but stability security more dominates religious tolerance effort. In reality, however, tension and opposition still occur. One of the reasons is concerning the problem of spreading religions (preaching, sending, mission). In this case, tension implies that religions become disintegrative aspects. To overcome the issue, the government has carried out inter-religions leaders dialogues, but the effort is considered less successful because mutual agreement regarding the principles of the spread of religion has not been achieved (Artanto, 1999).

Religious communities all over the world begin to have the awareness that followers of different religions aware to make social harmony and brotherhood rather than hostility. The idea is essentially the fundamental understanding of every religion. It is not just ideas but also an obligation that must be carried out and realized in reality by every religious community. The existence of this sacred duty is found in every religion and is formulated in different sentences both in words and nuances, but it is the same in essence.

Religious expression in maintaining harmony among religious communities in Indonesia must help each other as human beings, must be able to accept the different religions and their followers to achieve reality in multicultural societies. In essence, the awareness on understanding each other enables to achieve harmonious life among religious communities.

It becomes the responsibility of religion to manifest the meaning of religion in social interaction, such as the right of people to life, physical wholeness, and free development. Then, as its implication is the right of protection against arbitrary detention, legal guarantees, equality before the law, rights not to be tortured or treated cruelly and inhumane, the prohibition of slavery, the right to freedom of conscience, thought and religion, the right of prayer, freedom of giving opinion and freedom of press, freedom of assembly and association, right of personal property, right of getting jobs and right of getting married or not, as well as right to run business. In this case, it aims at determining national gathering life and getting the right to education for all citizens.

Nowadays, it is realized that technology in modernization provides space for all religious people in a country to get wider services, "Because after all the ideas referring to social tolerance and togetherness in differences will be in vain when some people still feel afraid of freely expressing aspirations (Setyaningrum, 2003). The construction of logic must be reflected in harmonious social relations and stop extremism in religious practice in Indonesia.

\section{Conclusion}

Finally, the Creator becomes a brother to everyone. In this case, the Creator implies more solid with humans so that they can get to know their Creator religiously. The most important thing done by religious people is to aware and take care of weak, poor, neglected, and oppressed brothers and sisters as a reflection of love to God expressed in real actions. Conversely, if it is not done, it means not to love God.

Religion is present as a manifestation of the Creator's love for societies. A society where humans can live religiously and according to their dignity as a manifestation of the Creator. Therefore, religion is a guide to actualize togetherness in social life based on love and justice. It implies religious moderation referring to achieving the right of living harmoniously with the dignity of their humanity. That is why religious people must be at the forefront of the struggle for human rights. The human rights of all brothers, regardless of any tribe or religion. Religion is expected not only to teach the entity of heaven but also to ensure the awareness of togetherness life as well as help each other among religious communities to achieve social harmony. 
Finally, the elaboration that has been written coherently and continuously based on fundamental and empirical theories is constructed without negation with the perspective of dissolving social problems. The social dynamic is harmonized by caring for and maintaining harmony in the plurality of Indonesia, and religious moderation as logical construction that should be contextualized continually according to the structure and texture of technological sophistication.

\section{Acknowledgments}

The writer would like to express cordial gratitudes towards friends and colleagues who have been helping on making this writing possible. Thanks toward Jeni Ishak Lele M.Th., Daniel Trihandarkha, M. Th., Petrus Marija, M. Th., Dr. Iswanto., Dr. Yohanis Siahaya., Prof. Dr. Teguh Prasetya, M.Si, and Prof. Dr. Ir. Sunarru Samsi Hariadi, M.S., for their insight and directions toward the relevant goal of this research.

Kawangung, Y. (2019). Religious moderation discourse in plurality of social harmony in Indonesia. International Journal of Social Sciences and Humanities, 3(1), 160-170. https://doi.org/10.29332/ijssh.v3n1.277 


\section{References}

Ariyanto, D. Subagyo. 2004. Genetic viability and evaluation heterosis in crosses between strains within common carp species. Zuriat, 15(118), e24.

Atmaja, I.B.O.P. (1996). Manusia Seutuhnya dari Sudut Ajaran Hindu" dalam Peranan Agama-Agama Dan Kepercayaan Terhadap Tuhan Yang Maha Esa Dalam Negara Pancasila Yang Membangun. Jakarta: BPK Gunung Mulia.

Bouman. (2004). Sistem Sosial Indonesia. Yogyakarta: STPMD.

Carson, D. A. (2002). The gagging of God: Christianity confronts pluralism. Zondervan.

Clendenin, D. B. (1995). Many gods, many lords: Christianity encounters world religions. Baker Books.

Cooley, F.l. (1997). Panggilan Kristen Dalam Hubungan Antar Umat Beragama" dalam Bunga Rampai Mengenang HUT ke - 70 dari P.D. Latuihamallo: Konteks Berteologi di Indonesia. Jakarta: BPK Gunung Mulia.

Diputhera, I.G.N.O. (1996). Toleransi dan Kebebasan Beragama Telah Menjadi Pandangan HidupBangsa Indonesia" dalam Peranan Agama-Agama Dan Kepercayaan Terhadap Tuhan Yang Maha Esa Dalam Negara Pancasila Yang Membangun. Jakarta: BPK Gunung Mulia.

Direktorat Bimas Kristen. (2018). Pidato Direktur Jenderal Bimas Kristen dalam Majalah Pelita Kristen Media Informasi \& Komunikasi Bimas Kristen. Jakarta: Ditjen Bimas Kristen.

Direktorat Bimas Kristen. (2018). Pidato Presiden dalam Majalah Pelita Kristen Media Informasi \& Komunikasi Bimas Kristen. Jakarta: Ditjen Bimas Kristen.

Direktorat Bimas Kristen. (2019). Mozaik Moderasi Beragama Dalam Perspektif Kristen oleh Thomas Pentury. Jakarta: BPK Gunung Mulia \& Ditjen Bimas Kristen.

Direktorat Bimas Kristen. (2019). Mozaik Moderasi Beragama Dalam Perspektif Kristen oleh Sumanto AlQurtuby. Jakarta: BPK Gunung Mulia \& Ditjen Bimas Kristen.

Direktorat Bimas Kristen. Pidato Menteri Agama dalam Majalah Pelita Kristen Media Informasi \& Komunikasi Bimas Kristen. Jakarta: Ditjen Bimas Kristen.

Dirjen Bimas Kristen Kementerian Agama RI, Direktori Gereja-Gereja, Yayasan. (2011). Pendidikan Agama dan Keagamaan Kristen di Indonesia. Jakarta: Aristik Citra Nuansapratama.

Efendi, D. (1996). Agama, Ideologi dan Politik Dalam Negara Pancasila", dalam Pancasila Yang Membangun," dalam Peranan Agama-Agama Dan Kepercayaan Terhadap Tuhan Yang Maha Esa Dalam Negara Pancasila Yang Membangun. Jakarta: BPK Gunung Mulia.

Latuihamallo, P.D. (1999). Fungsi Etika Sosial Dalam Masyarakat Majemuk" (peny.) Pramudianto dan Martin L. Sinaga., dalam Pergulatan dan Kontekstualisasi Pemikiran Protestan Indonesia. Jakarta: BPK Gunung mulia.

Manalu, S. R., Santosa, H. P., \& Luqman, Y. (2007). Teori Relational Dialectics Dalam Konteks Relasi Budaya Jawa. Jurnal Ilmu Sosial, 6(1), 20-31.

Masduki, M. (2014). Filosofi Interaksi Sosial Lintas Agama: Wawasan Islam. Toleransi, 6(1), 107-122.

Nugroho, T. (2003). Filsafat Manusia. Yogyakarta: APMD.

Permadi, K. (1996). Peranan Agama-Agama Dan Kepercayaan Terhadap Tuhan Yang Maha Esa." Dalam Pancasila Yang Membangun" dalam dalam Peranan Agama-Agama Dan Kepercayaan Terhadap Tuhan Yang Maha Esa Dalam Negara Pancasila Yang Membangun. Jakarta: BPK Gunung Mulia.

Robiyanto, F., Kanzanuddin, M., \& Martino, A. (2015). Persepsi Akademisi Mengenai Peranan Kehidupan Beragama di Indonesia Dalam Perspektif Sosial Budaya (Studi Pada Universitas Muria Kudus). Jurnal Sosial Budaya, 5(1), 1-10.

Sairin, W. (Ed.). (2002). Kerukunan umat beragama pilar utama kerukunan berbangsa: butir-butir pemikiran. BPK Gunung Mulia.

Sekertariat Negara Indonesia. (1983). Undang-Undang Dasar. Jakarta: CV Remeo Indonesia.

Setyaningrum, A. (2003). Multikulturalisme Sebagai Identitas Kolektif, Kebijakan Politik dan Realitas Sosial. Jurnal Ilmu Sosial dan Politik, 7(2003).

Sharif, M. (2004). Religious-historical perspective on conflicts and violence: Secular materialism versus spiritual humanism. International journal of sociology and social policy,24(1/2), 56-85. https://doi.org/10.1108/01443330410790966

Simatupang, T. B. (1995). Iman Kristen dan Pancasila.

Sudomo. (2002). Beberapa Pemikiran Sekitar Pembangunan Rumah Ibadah", dalam Kerukuranan Umat Beragama (ed) Wainata Sairin. Jakarta: BPK: Gunung Mulia. 
Sutarno. (2004). "Tanggung Jawab Etis Terhadap Politik" (peny. Daniel Nuhamara, dkk.) dalam Didalam Dunia Tetapi Tidak Dari Dunia. Jakarta: BPK Gunung Mulia dan Salatiga: Satya Wacana University Press.

Tim Pembinaan Penataran Pegawai Republik Indonesia. (1981). Bahan Penataran. Jakarta: TPPRI.

Widi, A. (1997). Menjadi Gereja Misioner dalam Konteks Indonesia. Jakarta: BPK Gunung Mulia dan Kanisius: Yogyakarta.

Yewangoe, A. A. (2002). Iman, Agama, Dan Masyarakat Dalam Negara Pancasila. Bpk Gunung Mulia.

Kawangung, Y. (2019). Religious moderation discourse in plurality of social harmony in Indonesia. International Journal of Social Sciences and Humanities, 3(1), 160-170. https://doi.org/10.29332/ijssh.v3n1.277 


\section{Biography of Author}

\begin{tabular}{|l|l|}
\hline & $\begin{array}{l}\text { Yudhi Kawagung, having studied in Doctorate Program of Theological Sekolah } \\
\text { Tinggi Teologi Kadesi Yogyakarta-Indonesia, keeping his passion at teaching at } \\
\text { Sekolah Tinggi Agama Kristen Teruna Bakti Yogyakarta, Indonesia and doing } \\
\text { academic writing in Theological Journal such as Matheteuo Volume 6, Ed. Juni, } \\
2018 \text { namely "Politik Kepemimpinan Umat Sebagai Wujud Hidup Mengereja } \\
\text { (Diskursif Tafsiran 1 Petrus 5:1-11);" Bijak: Basileia Indonesian Journal Kadesi } \\
\text { Volume 1, Ed. May 2, 2018, "Realitas Umat Kristen Menjelang Kedatangan } \\
\text { Kristus"; Jurnal Marturia Volume 1, Ed. May 2013 "Analisa Teks Mazmur 110." } \\
\text { Email: ykawangung06@gmail.com }\end{array}$ \\
\hline
\end{tabular}

